\title{
ALGORITHMS OF MULTI FREQUENCY RADIOMETRY IN THE CONDITIONS OF BROADBAND INTERFERENCE
}

\author{
V.V. Orlov, O.A. Lytvynenko, V.V. Galanin \\ URAN-4 Observatory of IRA NASU, Odessa, Ukraine,uran4@te.net.ua
}

\begin{abstract}
The development of digital technologies for multi-frequency signal reception in the low-frequency range creates the prerequisites for the application of optimal algorithms for real-time beamforming without changing the aperture of the radio telescope antenna.

In the present paper, a model of the system based on multiplicative processing (MP) is considered and investigated. The system consists of two antenna arrays, the signals from the outputs of which pass through the narrowband filters of receiving devices. After filtration, they undergo MP and weighted summation. Next, we consider an algorithm for the formation of a narrow beam of the antenna pattern (AP) of a multi-frequency radio interferometer based on the well-known cosinusoid summation method. Its meaning lies in summing up the results of multiplicative processing of signals from the outputs of several spatially separated different scales bases. In work, using MP, a method is proposed for reducing the width of the main lobe of AP on one base by receiving signals at several frequencies. The further development of the method is associated with the optimization of the AP in multifrequency MP, which leads to the possibility of lowering the side-lobe levels by weighing the signals from the outputs of the MP channels. For this purpose, for the sum of odd cosine waves, it is necessary to determine the weighting factors that ensure the minimum root-mean-square level of side lobes in a given zone of AP suppression. As a result of MP processing, we obtain a decrease in the amplitudes of side lobes with an insignificant increase in the width of the antenna pattern of the antenna system. In work the algorithm of suppression of broadband hindrances is also considered. The synthesis of the optimization algorithm is reduced to the need to determine the weighting coefficients and frequencies that provide the minimum rms level of the side lobes of the AP in a given zone of suppression, with a limited range of frequency separation. These methods are proposed to use in radio astronomy to improve the quality of research.
\end{abstract}

Keywords: antenna array, multiplicative processing, optimization, antenna pattern.

АБСТРАКТ. Розвиток цифрових технологій для багаточастотного прийому сигналів у низькочастотному діапазоні створює передумови для застосування оптимальних алгоритмів формування діаграми спрямованості (ДС) в реальному часі без зміни апертури антени радіотелескопа.

У представленій роботі розглядається й досліджується модель системи на основі мультиплікативної обробки (MO). Система складається із двох антенних решіток, сигнали 3 виходів яких, проходять через вузькосмугові фільтри приймальних пристроїв. Після фільтрації вони піддаються МО й ваговому підсумовуванню. Далі розглядається алгоритм формування вузького променя діаграми спрямованості багаточастотного радіоінтерферометра на основі відомого методу підсумовування косинусоїд. Зміст його полягає в підсумовуванні результатів мультиплікативної обробки сигналів з виходів декількох просторово рознесених двоканальних баз різного масштабу. У роботі, використовуючи $\mathrm{MO}$, пропонується метод зменшення ширини головного пелюстка ДС на одній базі за рахунок прийому сигналів на декількох частотах. Подальший розвиток методу пов'язаний 3 оптимізацією ДС у багаточастотній МО, що приводить до можливості зниження рівня бічних пелюстків за рахунок зважування сигналів 3 виходів каналів МО. Для цієї мети, для суми непарних косинусоїд необхідно визначити вагові коефіцієнти, що забезпечують мінімальний середньоквадратичний рівень бічних пелюстків у заданій зоні зниження рівня ДС. У результаті МО обробки одержуємо зменшення амплітуд бічних пелюстків при незначному збільшенні ширини ДС антеної системи. У роботі розглядається так само алгоритм зменшення широкосмугових завад. Синтез алгоритму оптимізації зводиться до необхідності визначення вагових коефіцієнтів і частот, що забезпечують мінімальний середньоквадратичний рівень бічних пелюстків ДС у заданій зоні зниження, при обмеженому діапазоні розносу частот. Перераховані методи пропонується використати в радіоастрономії для поліпшення якості проведених досліджень.

Ключові слова: антенна решітка, мультиплікативна обробка, оптимізація, діаграма спрямовованості.

\section{Introduction}

Striving for the effective use of decameter wavelengths in radio astronomy leads to the need to improve hardware and algorithmic tools to: increase the samplel signal size, increase noise immunity, and improve the quality of the 
antenna pattern (AP) of the antenna with limited aperture sizes (Men, 1997 ), (Konovalenko, 2016). An effective way to increase the sample size is to use the properties of the broadband signal, due to which sample accumulation can be performed at several frequencies (Men, 2000), (Shaw, 1965). In this case, it is necessary to take into account the dependence of the AP shape on the carrier frequency, especially the width of the main lobe and side lobes. The development of digital technologies for multifrequency signal reception in the range of $10-200 \mathrm{MHz}$ also creates prerequisites for the application of optimal AP formation algorithms in real time without changing the aperture of the radio telescope (RT).

This article proposes algorithms for optimizing AP due to signal processing at several frequencies. A system of radiometry based on multiplicative multi-frequency signal processing is being modeled, the possibilities of minimizing the level of side lobes of AP are being investigated.

\section{Model of the system under study}

The system under study based on multiplicative signal processing (fig.1) consists of 2 sub-arrays $A P_{1}, A P_{2}$, the signals from whose outputs pass through are $\Phi_{1 l}, \Phi_{2 l}$ narrow-band filters $l=1, . ., L$ of receivers tuned to $\omega_{l}$ frequencies, then subjected to MP and weighted summation with coefficients $g_{l}$.

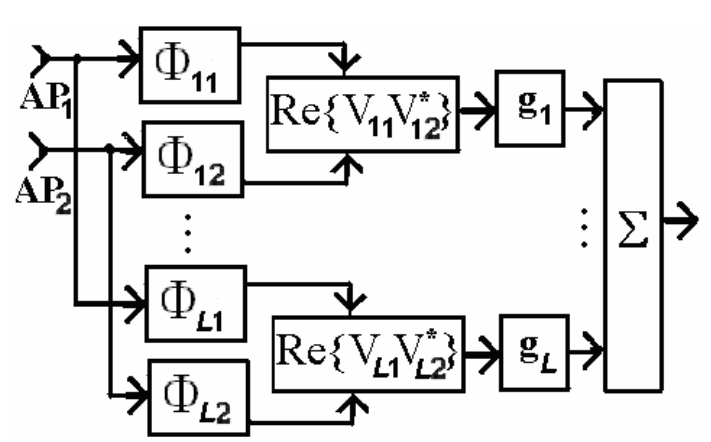

Figure 1: Radiometry system with multi-frequency processing

The model of a monochromatic point source of a signal from the outputs of a pair of filters of the $l$ frequency channel of two omnidirectional antennas can be represented as

$$
\begin{aligned}
& U_{1 l}(t)=U \exp \left\{\left(\omega_{l}\left(t+t_{0}\right)+\varphi_{0 l}\right\}=U \exp \left\{\left(\omega_{l} t+\varphi_{0 l}+\psi_{l}\right)\right\}\right. \\
& U_{2 l}(t)=U \exp \left\{\left(\omega_{l}\left(t-t_{0}\right)+\varphi_{0 l}\right\}=U \exp \left\{\left(\omega_{l} t+\varphi_{0 l}-\psi_{l}\right)\right\},(1)\right.
\end{aligned}
$$

Where $t_{0}$ - the delay time of arrival of the wave front along the aperture of MP, the size of which $d=\lambda / 2=\pi \nu / \omega$ is matched with the wavelength $\lambda$, main (first) carrier frequency $\omega=\omega_{1}$, speed of wave propagation $v, \quad \psi_{l}=\omega_{l} t_{0}=\pi\left(\omega_{l} / \omega\right) \cos \varphi-$ the phase of spatial delay of the wave front arrival at the frequency $\omega_{l}, \varphi-$ the angle of the wave front arrival rela- tive to the normal of AP base , $\varphi_{0}-$ the initial phase. It is assumed that in filters $\Phi_{1 l}, \Phi_{2 l}, \quad l=1, . ., L$, the amplitude, phase and mutual frequency distortions are eliminated to the accuracy of power leveling in frequency channels $P=P_{l}=\left\langle U_{1 l} * U_{2 l}\right\rangle, \quad l=1, . ., L \quad$, where $<>$ are the averaging symbols of the process over time.

\section{Algorithm for the formation of a narrow beam AP multifrequency radiointerferometer}

A known method of forming a narrow beam receiving antenna is the method of summing up cosinusoids (Denisov, 2002), which consists in summing the results of multiplicative processing of signals from the outputs of several spatially separated two-channel bases of different scale.

A method is proposed for reducing the width of the main lobe of the AP on one base by receiving signals at several frequencies. The signals $U_{1 l}, U_{2 l}$ from the outputs of a pair of filters tuned to odd $l=2 i-1$ frequencies are subjected to MP $\left.U_{\text {вы }}=\sum_{=1}^{L} g_{2 l-1} \operatorname{Re} U_{1,2 l-1} U_{2,2 l-1}^{*}\right\}=U^{2} \sum_{=1}^{L} g_{2 l-1} \cos \{(2 l-1) \psi\}$.

The output signal, taking into account the AP of the same sub-arrays $Y(\psi)$, determines the AP of multiplicative processing $D(\psi)$

$$
U_{\text {Bblx }}=U^{2} Y^{2}(\psi) \sum_{l=1}^{L} \cos \{(2 l-1) \psi\}=U^{2} Y^{2}(\psi) D(\psi)
$$

It is easy to show that when using odd frequencies and equal weights $\left(g_{l}=1\right)$, the AP MP is determined by the relation (Gradstein, 1971)

$$
D(\psi)=\sum_{l=1}^{L} \cos \{(2 l-1) \psi\}=0,5 \sin (2 L \psi) / \sin (\psi)
$$

The level of maximum side lobes of AP (3) is $-6.6 \mathrm{~dB}$, while for linear $N=4 L$-elemental AP with the same beam width is $-13.2 \mathrm{~dB}$. The difference between them is explained by the fact that (3) determines the AP of the MP in power, and the AP of the linear AR has a similar form in amplitude.

\section{Optimization of AP of multi-frequency MP}

A further decrease in the level of side lobes of the AP $\mathrm{MP}$, it is possible to carry out by weighing the signals from the outputs of the MP channels. For the sum of odd cosinusoids, it is proposed to perform optimization in the following formulation: it is necessary to determine the weighting coefficients $g_{l}$ that ensure the minimum rootmean-square level of side lobes in a given zone of AP suppression.

The output signal with regard to (1) and (2) for odd frequencies, taking into account the AP of the same subarrays $Y(\psi)$, determines the AP of multiplicative processing $D(\psi)$

$U_{\text {вblx }}=U^{2} Y^{2}(\psi) \sum_{=1}^{L} \cos \{(l-1) \psi\}=U^{2} Y^{2}(\psi) D(\psi)$, 
Imagine the normalized signal at the output of the $L$ - frequency MP in the form

$$
y=U_{\text {вblx }} / U^{2}=G^{T} X,
$$

where $X^{T}=\{\cos \phi, \cos 2 \phi, . ., \cos (2 L-1) \phi\}-$ the vector of signals of the angular direction $\varphi$ from the outputs of MP, $G^{T}=\left\{g_{1}, g_{2}, . ., g_{L}\right\}$ - the vector of weighting coefficients. Then the function $H$ minimized by the vector, with the signal $S^{T}=\{1,1, . ., 1\}$, with the angular position in the maximum of the $\operatorname{AP}(\varphi=0)$, is determined by the expression

$$
H=\min _{G} \int_{z} y^{2}(\varphi) d \varphi, \quad \text { nрu } \quad G^{T} S=L
$$

Where $z$ - the side lobe suppression zone, $z \in[K \pi / 2 L, \pi / 2], K-$ the coefficient of expansion maxim AP.

In the matrix form (6) has the form (7)

$$
H=\inf _{G^{T} S=L} G^{T} R_{X X} G,
$$

where $R_{X X}$ - the correlation matrix of the input signal with the elements

$$
\begin{aligned}
& r_{i j}=\int_{z} \cos [(2 i-1) \phi] \cos [(2 j-1) \phi] d \phi= \\
& = \begin{cases}-0,5\left(\frac{\sin K \pi(i+j-1) / L}{i+j-1}+\frac{\sin K \pi(i-j-1) / L}{i-j-1}\right), i \neq j \\
\pi / 2-K \pi / 2 L-\frac{\sin K \pi(2 i-1) / L}{4 i-2}, & i=j\end{cases}
\end{aligned}
$$

To find the vector $G$, the method of indeterminate Lagrange multipliers $\alpha$ is used and an auxiliary function (Burakov, 1976) $B=0,5 G^{T} R_{X X} G+\alpha\left(S^{T} G-L\right)$ is introduced. After equating the derivative to zero $d B / d G=$ 0 , the solution of the resulting equation is

$$
G=R_{X X}^{-1} S\left(S^{T} R_{X X}^{-1} S\right)^{-1} L .
$$

On Fig. 2 shows the antenna pattern consisting of two dipoles ( line 1), the same antenna, but using MP with the same weights (line 2) and the same antenna, but with optimized weighting coefficients (line 3 ).

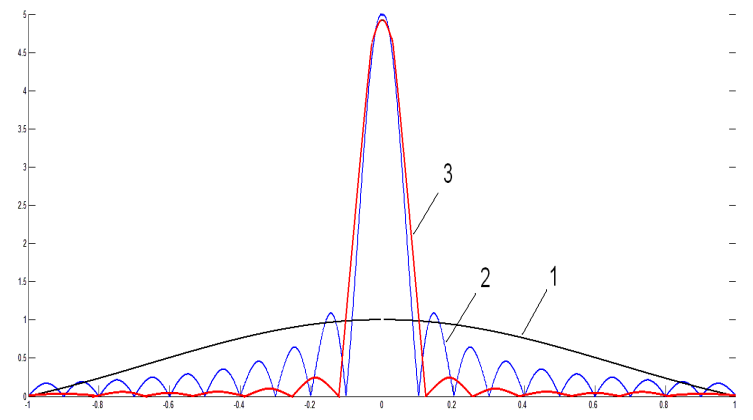

Figure 2: Optimization of the antenna pattern
Analysis of AP MP with weight processing (9) showed that with a given widening of the main lobe $K=1.1$, the level of the maximum side lobe is $-11.2 \mathrm{~dB}$, and for the zone of moderate expansion of the main lobe $(K<2.5)$ the level of the maximum side lobe decreases up to $-21 \mathrm{~dB}$.

\section{Algorithm for suppressing broadband interfe-} rence

The possibilities of lowering the side lobes of the AP in a narrow frequency separation range (as compared with the previous algorithm), with a deviation from the reference frequency $\omega=\omega_{1}$ in the range $(1 \ldots 1.5) \omega$ are investigated. The reduction of the root-mean-square level of side lobes of the antenna array antenna pattern can be carried out in a given region, if in the whole region the maximum of the antenna directive gain is provided.

The optimization algorithm is synthesized in the following formulation: it is necessary to determine the weighting coefficients and frequencies that ensure the minimum of the root-mean-square level of side lobes of the AP in a given suppression zone, with a limited frequency separation range.

The output signals of the adjacent equidistant $N$ element sub-arrays 1 and 2 at an arbitrary carrier frequency $\omega_{l}$, taking into account (1) and (2), have the form

$U_{1 l}(t)=\sum_{i=1}^{N} U \exp \left\{j\left[\omega_{l}\left(t+t_{0}(i-1)\right]+\varphi_{0 l}\right\}=\right.$

$=\sum_{i=1}^{N} U \exp \left\{j\left(\omega_{l} t+\varphi_{0 l}+(i-1) \psi_{l}\right)\right\}=$

$=\frac{U \sin \left(N \psi_{l} / 2\right)}{\sin \left(\psi_{l} / 2\right)} \exp \left\{j\left(\omega_{l} t+\varphi_{0 l}+(N-1) \psi_{l} / 2\right)\right.$

$U_{2 l}(t)=\frac{U \sin \left(N \psi_{l} / 2\right)}{\sin \left(\psi_{l} / 2\right)} \exp \left\{j\left(\omega_{l} t+\varphi_{0 l}-(N-1) \psi_{l} / 2\right)\right.$,

where $\psi_{l}=\omega_{l} t_{0}=\pi\left(\omega_{l} / \omega\right) \sin \varphi-$ the phase of the spatial delay of the arrival of the wave front at the frequency $\omega_{l}, \varphi$ - the angle of the arrival of the wave front relative to the normal to the array, taking values in the interval $[-\pi / 2, \pi / 2]$.

Then the output signal after summing the frequency channel responses is determined

$$
\begin{aligned}
& U_{\text {выx }}=\operatorname{Re}\left\{U_{1, l} U_{2, l}^{*}\right\}= \\
& =U^{2} \sum_{l=1}^{L} g_{l}\left(\frac{\sin \left(N \psi_{l} / 2\right)}{\sin \left(\psi_{l} / 2\right)}\right)^{2} \cos \left\{\psi_{l}(N-1)\right\}
\end{aligned}
$$

Similar to the method of the previous optimization of the AP, we represent the normalized signal (10), as a function of the angle $\varphi$ of arrival of the wave, at the output $L$ frequency MP as

$$
y=U_{\text {вblx }} / U^{2}=\sum_{l=1}^{L} g_{l} x_{l}(\varphi)=G^{T} X,
$$

where the elements $X$ of the vector signals from the $L$ outputs of the MP are determined by the expression 


$$
x_{l}=\left(\frac{\sin \left(N \pi\left(\omega_{l} / 2 \omega\right) \sin \varphi\right)}{\sin \left(\pi\left(\omega_{l} / 2 \omega\right) \sin \varphi\right)}\right)^{2} \cos \left\{(N-1) \pi\left(\omega_{l} / \omega\right) \sin \varphi\right\}
$$

Then the function $H$ minimized by the vectors $G, \Omega$, with the signal $S^{T}=\{1,1, . ., 1\}$, with the angular position at the peak of the $\operatorname{AP}(\varphi=0)$, is determined by the expression

$$
H=\min _{G, \Omega} \int_{z} y^{2}(\varphi) d \varphi, \quad \text { npu } \quad G^{T} S=L
$$

where the minimization of the functional is carried out along two vectors $G, \Omega$ of variables, $z$ - the side-lobe suppression zone, $z \in\left[\varphi_{1}, \varphi_{2}\right], \Omega^{T}=\left\{\omega_{1}, \ldots, \omega_{L}\right\}-$ selected frequencies containing wideband interference. If the set of $M$ frequencies $\Omega$ is predetermined and its size $M=L$ coincides with the size of the vector $G$, then the optimization problem is solved by the previous method. If it is necessary to select $L$ individual channels of multichannel reception from the full set of all $M>L$ frequencies, optimization (11) is carried out for each combination of the $M$ and $L$ then, after going through all the combinations, the global minimum is determined. Reduction of computational operations can be achieved using a priori information about the number of interference and the zone of possible interference directions. There is a known theorem (Shirman, 1974) that for the complete suppression of $\mathrm{M}$ point-like interference, additional $\mathrm{M}$ frequency channels of are sufficient. From this it follows that to suppress 1 point interference, 1 additional frequency channel is sufficient. In this case, the choice of the frequency at which the amplitude of the side lobe is equal and opposite in the direction of interference of the main and additional frequency channels is the simplest. The suppression adjustment is implemented by a single multiplier.

The zone of possible interference suppression is determined by the objectives. If it is necessary to suppress the signal of an interfering space radio source that falls into the side lobe of the AP, then the range of angular directions $\left(\varphi_{1}, \varphi_{2}\right)$ is known. In this case, only individual side lobes corresponding to the interfering radio source are minimized. If it is necessary to compensate for interference from terrestrial radio stations (RFI2010, 2010), then side lobes are minimized in a given zone of large angles $\left(\varphi_{1}, \varphi_{2}\right)$. On Fig. 3 shows the APs of the 64-element antenna sub-arrays, $\mathrm{N}=64$, for two frequency channels with frequency detuning $\omega_{2} / \omega_{1}=1.1$. The analysis of dependences showed that for two-frequency processing with an angular separation of radio sources of more than 1.4 degrees, side lobes may already have different signs in the frequency channels.

In radio astronomical signal processing systems, various methods of adaptation to changes in the parameters of the ionosphere and to disturbing radio sources began to be introduced (Barnbaum, 1998),

(Afroimovich, 2008). The proposed approach allows adaptation by selecting frequencies and already with twofrequency processing $L=2$, forming zeros in the direction of the interfering radio source.

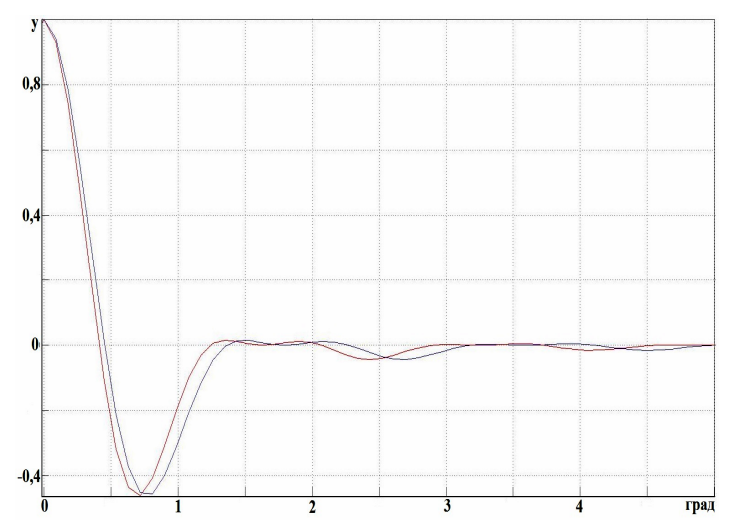

Figure 3: AP of two frequency channels

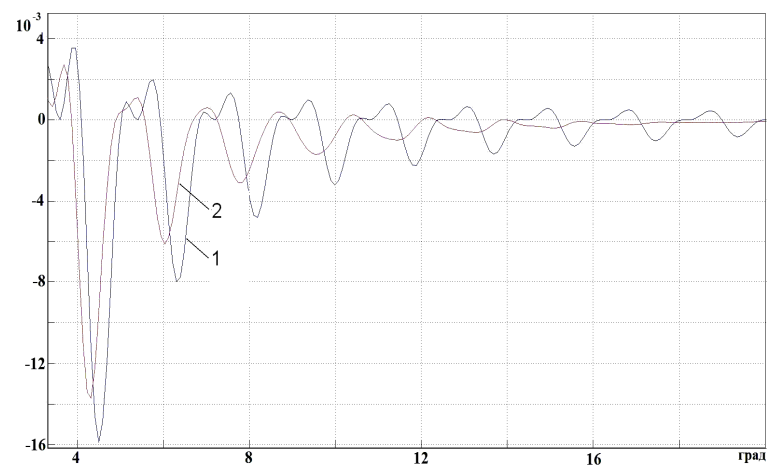

Figure 4: The side lobes of the AP at the same frequency and with averaging over the frequency range

In practice, to reduce the level of side lobes of the AP, a quasi-optimal algorithm is often used, which consists in averaging (10) in the frequency range from to with constant weighting coefficients. In Fig. 4 shows the fragments of the side lobes of the AP at the initial frequency (line 1) and when averaged in a uniform grid of the frequency range $\omega_{L} / \omega_{1}=1.1, L=100$ (line 2).

It is easy to see that the efficiency of the averaging method is insignificant for angles less than 4 degrees and significantly increases with large angular detuning of the studied and interfering radio sources.

\section{Conclusion}

The proposed approach expands radiometry capabilities in relation to radio astronomy in the formation of AP due by time processing in frequency channels. Open the way to adapt to interference without the use of auxiliary antennas. Computational methods of adaptive processing are realizable in real time, taking into account the rotation of the Earth, scanning the beam and the angular location of interfering cosmic sources.

In general, the choice of frequency grid and weighted multi-frequency signal processing provide a reduction in the width of the main beam of the beam with limited antenna aperture sizes, an increase in the signal-to-noise ratio, as well as a decrease in side lobe level and interference effects. 


\section{References}

Afraimovich E., Smolkov G. et al.: 2008, in Rep. of the Academy of Sciences Astronomy, Astrophysics, Cosmology, 419, No. 5, 618.

Barnbaum, C., Bradley R. F.: 1998, Astron. J., 116, 2598.

Burakov V. et al.: Foreign Radioelectronics, 8, 35.

Denisov V. et al.: 2002, Phase direction finders. Monograph. (Tomsk: TUSUR), 251.

Gradstein I., Ryzhik I.: 1971, Tables of integrals, sums, series and products.

Konovalenko A., Erin S. et al.: 2016, Radio Physics and Radioastronomy, 21, No. 2, 83.
Megn A., Braude, S. et al.: 1997, Radio Physics and Radio Astronomy, 2, No. 4, 385.

Megn A., Braude S.: 2000, Radio Physics and Radio Astronomy, 5, № 1, 5.

RFI2010, 2010.: Overview of RFI mitigation methods in existing and new systems (invited) ( RFI mitigation workshop. RFI2010. 29-31 March 2010. Groningen, the Netherlands. https://pos.sissa.it/107/. RFI2010_007.pdf).

Shirman J.: 1974, Resolution and compression of signals. (M.: Soviet Radio), 360.

Shaw E., Davis D.: 1965, Foreign Radioelectronics, 11, 103. 